\title{
Contemporary Russian Conservativism: Problems, Paradoxes, and Perspectives
}

\author{
Mikhail Suslov \& Dmitry Uzlaner (red.) \\ Leiden/Boston: Brill 2020 \\ 426 sider. ISBN 9789004401907
}

Anmeldt av Pål Kolstø [professor i Russland-studier, Universitetet i Oslo, pal.kolsto@ilos.uio.no]

Etter de omfattende demonstrasjonene mot Putin-regimet vinteren 2011-2012 fant det sted et merkbart skifte i den offisielle russiske retorikken. Dmitrij Medvedevs vektlegging av «modernisering» ble avløst av «konservatisme». En del russiske intellektuelle hadde allerede i flere år gitt ut bøker og artikkelsamlinger som forkynte konservatisme som løsningen på Russlands problemer, og nå kom dette budskapet til uttrykk også gjennom offisielle kanaler. Det ville riktignok være misvisende å snakke om en ny russisk statsideologi - noe den russiske grunnloven nedlegger et eksplisitt forbud mot. Putin er i første rekke pragmatiker og realpolitiker, og han har kommentert den nye konservatismen kun ved et par anledninger. I sin tale til nasjonen $\mathrm{i}$ desember 2014 siterte han med tilslutning den russiske tenkeren Nikolaj Berdjajev, som en gang bemerket at hensikten med konservatisme ikke er å stoppe framskritt, men å forhindre reaksjon bakover. Ved andre anledninger har Putin vist til den russiske eksilfilosofen Ivan Ilin, som er et stort navn for russiske konservative i dag.

Contemporary Russian Conservativism springer ut av en internasjonal konferanse som ble avholdt i mai 2017 i Uppsala, der den ene av bokens redaktører, Mikhail Suslov, arbeidet (han har senere flyttet til København). Også flere av de andre bidragsyterne er skandinaver eller jobber i Sverge, så boken kan betraktes som en skandinavisk produksjon.

Boken består av hele 15 kapitler av forskjellige forfattere. Farene ved et slikt omfattende verk er to: På den ene siden kan boken lett falle fra hverandre i en serie artikler som spriker i alle retninger, eller motsatt, at forfatterne tråkker i beina på hverandre og gjentar mange av hverandres poenger. I denne boken har man på mesterlig vis manøvrert mellom Skylla og Kharybdis. Alle kapitlene forholder seg direkte til den overordnede problematikken samtidig som de tar opp én spesifikk side ved dette mangslungne fenomenet. Noe overlapping mellom kapitlene er ikke til å unngå, 
men den er meget begrenset. Samtidig har jeg vanskelig for å se at det er vesentlige aspekter som er oversett. Dette må man kunne si er en bragd.

I en kort anmeldelse vil det være umulig å gi en full presentasjon av alle kapitlene $i$ et så omfattende verk, så jeg må nøye meg med å gi en oversikt over hvilke temaer som tas opp i de seks hoveddelene som boken er delt inn i. I del 1 gir et kapittel med hele fire forfattere en grei oversikt over konservatismens historie i Russland. Mens det er de radikale og revolusjonære forfatterne på 1800-tallet som nok er best kjent i vesten, får kapitlet godt fram at landet har fostret også mange konservative tenkere, selv om noen av disse - ut fra Putins definisjon i hvert fall - kanskje burde vært rubrisert som "reaksjonære» snarere enn som konservatory. En i overkant vid definisjon av «konservatisme» kan man finne også i noen av de andre kapitlene. For eksempel blir Aleksander Dugin innlemmet blant dagens russiske konservative, til tross for at han vel snarere bør anses som høyreradikaler.

Del 2 tar for seg konservatisme som begrep og ideologi i dagens russiske kulturdebatt. «Konservatisme»-merkelappen brukes av og om mange tenkere og politikere som har svært forskjellig ståsted, så en slik terminologisk drøfting er absolutt nyttig. Og selv om den gamle sovjetiske etterretningsoffiseren Vladimir Putin altså selv neppe har konvertert til ideologisk konservatisme, så har flere profilerte stemmer i det russiske offentlige ordskiftet for tiden gjort nettopp det.

Del 3 går nærmere inn på noen av de miljøene og tenketankene som i de senere årene har forfektet et konservativt budskap i Russland, og på hvordan disse har beveget seg fra randfenomen til mainstream. I sitt bidrag ettersporer Marlene Laruelle en av de ledende vestlige forskere på russisk konservatisme og nasjonalisme - hvordan russiske intellektuelle (og kvasiintellektuelle) på høyre fløy har funnet meningsfeller blant likesinnede i USA. Påvirkningen mellom disse to miljøene har gått begge veier, mener hun.

Del 4 tar for seg tenkere som diskuterer Russlands geopolitiske rolle i verden ut fra et konservativt ståsted, og som målbærer russisk eksepsjonalisme, messianisme eller isolasjonisme. Spesielt har jeg lyst til å framheve Ekaterina Grishaevas spennende kapittel «'Making Europe great again': anti-western criticism from Orthodox conservative actors online». Kapitlets tematikk er snever, men perspektivene er vide.

I del 5 forskyves synsvinkelen fra geografi til historie. Det sier seg nesten selv at konservative tenkere er opptatt av sitt lands historie og stolte fortid. Samtidig har Russland hatt en særdeles turbulent historie med mange voldsomme brudd, så som Peter den stores reformer og Oktoberrevolusjonen, så hvilken epoke skal de knytte an til? Man skulle tro at de fleste konservative russere ville ta avstand fra kommunisttiden, men som den norske idéhistorikeren Kåre Johan Mjør viser i sitt kapittel, er det mange som nekter å velge vekk 1900-tallet, og som oppfatter alle epoker som uttrykk for en særegen russisk sivilisasjon.

Bokens siste hovedbolk tar for seg en av viktigste aktørene og premissleverandørene i den nye russiske konservatismedebatten, den russisk-ortodokse kirke. Kirkens menn bruker riktignok ikke så ofte begrepet «konservatisme», men snakker heller 
om "tradisjonelle verdier» og om behovet for å demme opp for vestlig «liberalisme» og "globalisme». Under patriark Kirills lederskap har kirken forkynt dette budskapet også lenge før de statlige myndighetene begynte å etterape det, og fokuset på tradisjonelle verdier i russisk offentlig debatt er helt klart et uttrykk for kirkens betydelige gjennomslagskraft. Dette har nedfelt seg også i lovgivingen. Kirken har vunnet fram ikke bare i sin kamp for å forby blasfemi, men også i det den oppfatter som (kjerne) familiens interesser. Dette har utkrystallisert seg i en ny lov mot "propaganda blant mindreårige for ikke tradisjonelle (les: homofile) forbindelser» og en lov som avkriminaliserer «mildere» former for vold i nære relasjoner. Utrolig nok oppfattes det som at det er i familiens interesse at koneplagere får drive på uten noen form for reaksjon.

I den senere tiden er det ting som tyder på at referansene "til konservatisme» $\mathrm{i}$ det russiske ordskiftet er i ferd med å bli mindre hyppige. Kanskje er det et tegn på at dette bare var en merkelapp på en kampanje staten kjørte for å demme opp for den prodemokratiske demonstrasjonsbølgen vinteren og våren 2012. Putin vender tilbake til pragmatismen i sin politikk og retorikk. Men samtidig er mange av de håndfaste resultatene av denne kampanjen blitt stående (inntil videre?), så som den nye «tradisjonalistiske» lovgivingen og kirkens styrkede stilling. Russisk konservatisme og tradisjonalisme er derfor temaer vi bør følge nøye med på også i tiden som kommer. 